ISSN 1817-3721, E-ISSN 1818-8745

Plant Tissue Cult. \& Biotech. 29(1): 81-97, 2019 (June)

(CBangladesh Assoc. for Plant Tissue Culture \& Biotechnology

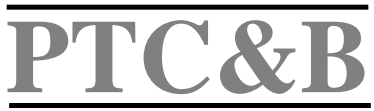

\title{
In vitro Regeneration and Agrobacterium-mediated Genetic Transformation of Local Varieties of Mungbean (Vigna radiata (L). Wilczek)
}

\section{Sujay Kumar Bhajan, Setara Begum, Mohammad Nurul Islam, M. Imdadul Hoque and Rakha Hari Sarker*}

Plant Breeding and Biotechnology Laboratory, Department of Botany, University of Dhaka, Dhaka-1000, Bangladesh

Key words: Mungbean, In vitro regeneration, Genetic transformation, nptll and GUS genes

\begin{abstract}
An efficient Agrobacterium-mediated transformation compatible in vitro regeneration protocol was developed for two important varieties of mungbean (Vigna radiata (L.) Wilczek) cultivated in Bangladesh, namely Binamoog-5 and BARI Mung-6. Two different zygotic embryo derived explants, such as cotyledonary node $(\mathrm{CN})$ and cotyledon attached decapitated embryo (CADE) were used for direct organogenesis of shoot. MS supplemented with $4.0 \mu \mathrm{M}$ BAP was found to be the best for the development of highest number of multiple shoots from CADE in both the varieties of mungbean. While in case $\mathrm{CN}$ the best shoot formation was achieved on MS containing $4.0 \mu \mathrm{M}$ BAP and $0.5 \mu \mathrm{M}$ NAA in both varieties. Half strength of MS with $2.0 \mu \mathrm{M}$ IBA was found to be most effective for producing healthy root from regenerated shoots. Following root induction, the in vitro raised plantlets were successfully transplanted to soil for their establishment. Considering overall responses, genetic transformation efficiency was found to be better with CADE explant using Agrobacterium tumefaciens strain LBA4404 harboring the binary plasmid pBI121 conferring GUS and nptII genes. Different factors influencing transformation was optimized during this study. Selection of transformed shoots was carried out by gradually increasing the concentration of kanamycin and such transformed shoots were eventually selected using $200 \mathrm{mg} /$ kanamycin. Stable expression of the GUS gene was detected in various parts of regenerated transformed plantlets. Transformed shoots were rooted on half strength MS containing $2.0 \mu \mathrm{M}$ IBA and $100 \mathrm{mg} /$ ticarcillin. Rooted transformed plantlets were successfully transferred to soil. Stable integration of GUS and nptII genes in the putative transformed shoots was confirmed through PCR analysis.
\end{abstract}

*Author for correspondence: <rhsarker2000@yahoo.co.uk>. DOI: https://doi.org/10.3329/ptcb.v29i1.41981 


\section{Introduction}

Mungbean (Vigna radiata (L.) Wilczek) is the most important grain legume as well as a cash crop in the rice-based farming systems of South and Southeast Asia and is also gaining popularity in other countries of the world. The cultivation of the crop extends across a wide range of latitudes $\left(40^{\circ} \mathrm{N}\right.$ or $\left.\mathrm{S}\right)$ in regions where the average day time temperature during the growing season is higher than about $20^{\circ} \mathrm{C}$. Currently, mungbean is cultivated on more than 6 million hectares worldwide (about $8.5 \%$ of global pulse cultivation area) and global annual production is 3 million tons (5\% of global pulse production). India is the largest mungbean producing country followed by China and Myanmar (Nair et al. 2014).

Vigna radiata belongs to Leguminosae and sub-family Papilionaceae. This crop is considered as a supreme quality pulse for its high contents of carbohydrate (56.7\%), protein $(24.5 \%)$, fat $(1.2 \%)$, minerals (3.5\%) vitamin, iron $(3 \mu \mathrm{g} / 20 \mathrm{~g})$ and lysine (504 $\mathrm{mg} / \mathrm{g}$ ) (AVRDC 2000). Mungbean is a potential source of dietary protein for human nutrition and as feed for livestock. Sprouted mungbean seeds provide a succulent, nutritious vegetable, rich in protein, minerals and vitamins (Poehlman 1991). It is generally regarded as an important item in vegetarian diet. Presently mungbean is cultivated globally for its high-quality nutritive seeds. Moreover, as a leguminous crop, it has unique ability to improve the soil fertility by fixing atmospheric nitrogen and depositing significant amounts of organic matter to the soil. It can be used in crop rotation practices as it is a short duration and low water requirement- plant and thus it is considered as an important crop for the future under climate change conditions. Other properties like easy digestibility and low proportions of flatulence factor also add to its value among the pulse crops. Short crop duration, low input requirement and high global demand make mungbean an ideal rotation crop for small holder farmers. It generates a triple benefit: additional income, additional nutrient-rich food and increased soil fertility. The demand for this crop has been steadily increasing all over the world and it has been playing an important role in fulfilling the nutritional requirements of global population.

In Bangladesh, mungbean is very popular among the pulses and ranks third in acreage and contributes $10-12 \%$ of total pulse production but ranks first in market price (BBS 2016). Yield of mungbean is generally unstable both over locations and seasons due to the susceptibility of mungbean cultivars to environmental stresses, diseases and insect pests. As a result, mungbean is often grown in marginal lands with minimal inputs (Shanmugasundaram and Kim 1996).

It is worth mentioning here that the average yield of mungbean is quite low in Bangladesh as compared to that of the other mungbean-growing countries of the region. Nevertheless, due to high consumer's demand, Bangladesh imports a large amount of mungbean seeds every year mostly from the neighboring countries. 
The main reason for low yield of this crop is the susceptibility to various specific diseases including yellow mosaic, Cercospora leaf spot, powdery mildew, root rot and insect pests, such as beanfly, aphids, pod borers, stink bugs, bruchids etc. Among the diseases mungbean yellow mosaic disease caused by mungbean yellow mosaic virus (MYMV) is the most damaging one in all mungbean growing areas (Nariani 1960, Shah et al. 2007, Borah and Dasgupta 2012). In some year's losses exceed more than $80 \%$ due to incidence of MYMV. Apart from the diseases several other factors are responsible for the lower production of mungbean, which includes: (i) Low genetic variability in locally cultivated varieties, (ii) yield fluctuates due to unusual environmental stresses including drought and salinity, (iii) photoperiod sensitivity, (iv) lack of synchronous pod formation, (v) incidence of insect infestation and (vi) poor cultural practices (Chand et al. 2015, Gnanaraj et al. 2015, Parihar et al. 2017).

Due to low yield potentials most of the farmers of Bangladesh are giving less priority to mungbean cultivation and are using marginal lands for this purpose. For the improvement of mungbean, relatively less attention has been paid compared to cereals and major pulses such as chickpea and lentil. Therefore, it is essential to improve this crop to obtain desired agronomic performance including resistance to diseases, high productivity, enhanced nutritional value and other essential agronomic quality this crop. The use of desirable genes from its related wild and cultivated species has been considered important in the genetic improvement of mungbean and other tropical pulses (Chavan et al. 1966, Verma and Singh 1986 and Bhadra et al. 1989).

To date investment in mungbean variety improvement has been very low, leading to a narrow genetic base of the crop. Consequently, current mungbean varieties lack key traits to cope with emerging pests, diseases and seasonal variability, which constrains production in South and Southeast Asian countries, as well as in Australia. In the past, several attempts have been undertaken to develop improved variety of mungbean through interspecific hybridization and mutation breeding. But classical breeding has met with limited success due to non-availability of gene/s of interest in the germplasm, high degree of self-pollinations well as cross-incompatibility between wild and cultivated varieties (Mirza and Tanzeen 2004).

Under these circumstances, there is considerable scope to exploit the modern techniques of biotechnology for the improvement of mungbean, commonly known as "plant genetic transformation". Genetic transformation is an emerging technology that can supplement traditional crop improvement procedure. This approach can be used in introducing desired genes, which is not possible through conventional breeding alone (Gardner 1993). Thus, genetic transformation enhances and broadens the genetic variability in several species where natural variability within a species is limited. A reproducible, reliable genetic transformation system could be useful to insert genes of interests in mungbean cultivars/varieties, which are unavailable in present genotypes. 
Agrobacterium-mediated genetic transformation has been demonstrated in a number of leguminous crops including soybean (Hinchee et al. 1988, Jacobsen 1992), pea (Schroeder et al. 1993), chickpea (Kar et al. 1996) and lentil (Sarker et al. 2003, Sarker et al. 2019).

To date very little information is available regarding genetic transformation of mungbean (Jaiwal et al. 2001, Sarker and Siddiqua 2004, Mahalakshni et al. 2006, Hoque et al. 2007, Islam and Islam 2010). Considering the importance as a major protein yielding crop in Bangladesh, in the present investigation attempts were made to develop an effective Agrobacterium-mediated genetic transformation protocol using screenable and selectable marker genes for two varieties of mungbean cultivated in Bangladesh. Moreover, special efforts were made to develop a genotype independent regeneration system for mungbean to facilitate Agrobacterium-mediated genetic transformation. The transformation protocol was optimized using GUS reporter gene through histochemical assay. Expression of GUS gene was detected by histochemical assay and integration of GUS and nptll genes were confirmed by PCR analysis.

\section{Materials and Methods}

Seeds of the two varieties of mungbean (Vigna radiata (L.) Wilczek) cultivated in Bangladesh, namely Binamoog-5 and BARI Mung- 6 were used as source of explants for this study. The seeds of Binamoog-5 and BARI Mung- 6 were obtained from Bangladesh Institute of Nuclear Agriculture (BINA), Mymensingh and Bangladesh Agriculture Research Institute (BARI), Joydevpur, Gazipur, respectively. These seeds were maintained in the Plant Breeding and Biotechnology Laboratory of the Department of Botany, University of Dhaka.

Two different types of zygotic embryo derived explants (Fig. 1), namely cotyledon attached decapitated embryo (CADE) and coteledonary node (CN) were used for in vitro regeneration as well as for Agrobacterium-mediated genetic transformation.
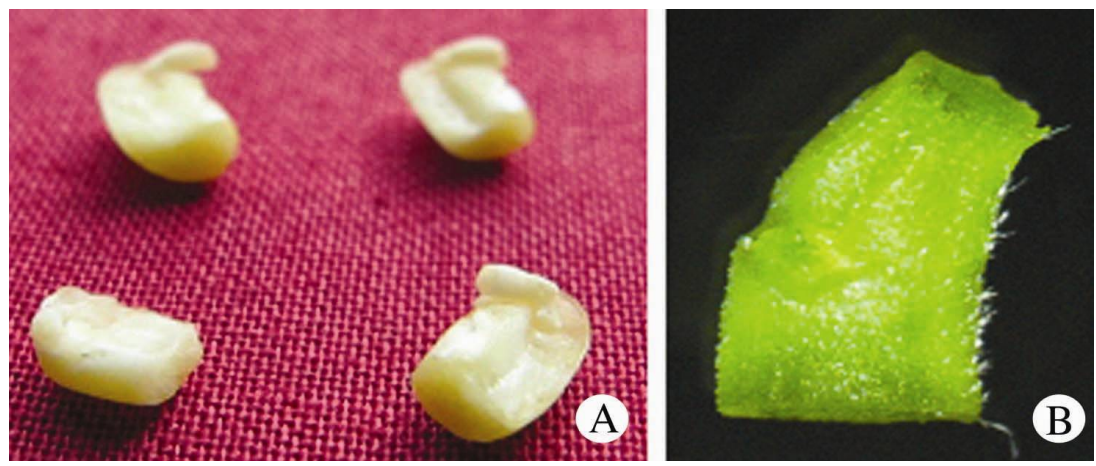

Fig. 1. Photographs of explants used in this study. A. Cotyledon attached decapitated embryo (CADE) and B. Coteledonary node $(\mathrm{CN})$ obtained from germinated young seedling of BARI Mung-6. 
For the preparation of explants, mungbean seeds were first washed in $70 \%$ ethanol for $1 \mathrm{~min}$, and then surface sterilized with $0.1 \%(\mathrm{w} / \mathrm{v}) \mathrm{HgCl}_{2}$ solution for $10-12 \mathrm{~min}$ with vigorous shaking. The seeds were then rinsed at least three times with sterilized distilled water and were kept in sterilized distilled water overnight. To get CADE explants, cotyledons were separated from soaked sterilized seeds. After removing seed coats, the seeds were split open and two cotyledons were separated. Embryos were found to be attached with one of the cotyledons. The shoot and root meristem from these embryos were decapitated. In case of $\mathrm{CN}$ the surface sterilized seeds were cultured on MS containing $3 \%(\mathrm{w} / \mathrm{N})$ sucrose with $1.2 \%(\mathrm{w} / \mathrm{N})$ agar without any growth regulators for their germination. After 3 - 4 days $\mathrm{CN}$ explants were collected from the young germinated seedling.

For initiation and development of shoot, agar solidified MS supplemented with various combinations and concentrations of $\mathrm{BAP}, \mathrm{Kn}$ and NAA were used for in vitro multiple shoot regeneration. All culture media contained 3.0\% sucrose with $0.8 \%$ agar having $\mathrm{pH} 5.8$, adjusted before autoclaving. In vitro regenerated shoots were subcultured regularly to fresh medium at an interval of 12 - 15 days for further multiplication of shoots. For the induction of roots in vitro grown $2-5 \mathrm{~cm}$ long regenerated shoots were excised and transferred to MS/half strength of MS supplemented with different concentrations of IBA, IAA. All cultures were maintained under $16 \mathrm{hrs}$ photoperiod at 25 $\pm 2^{\circ} \mathrm{C}$. The plantlets with sufficient number of roots were transplanted to small plastic pots containing sterilized soil for their establishment.

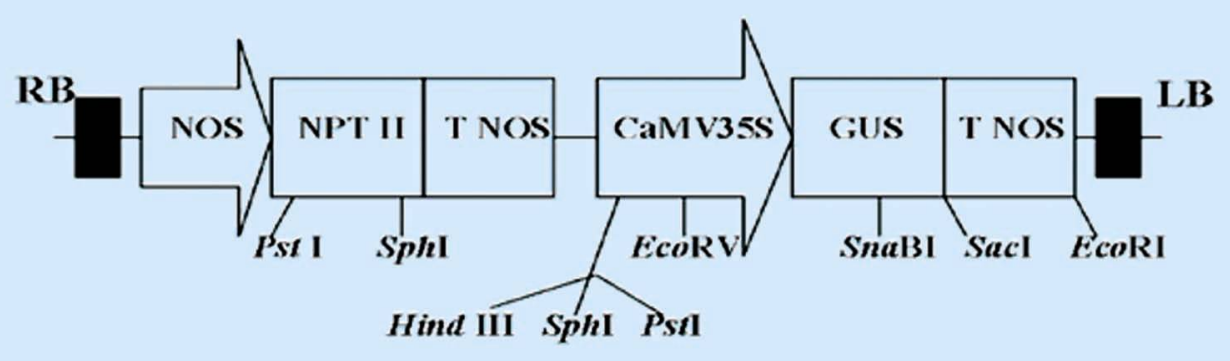

Fig. 2. Diagrammatic representation of T-DNA region between left (LB) and right (RB) border of pBI121 from Agrobacterium tumefaciens strain LBA4404.

Agrobacterium tumefaciens strain LBA4404 containing the binary plasmid pBI121 was used for genetic transformation (Fig. 2). The T-DNA region of the plasmid contains a scoreable reporter gene GUS driven by CaMV35S promoter and NOS terminator and a selectable marker gene nptII fused between NOS promoter and NOS terminator encoding for enzyme neomycin phosphotransferase conferring kanamycin resistance (HerreraEstrella et al. 1983). 
For genetic transformation, the prepared explants were submerged in the Agrobacterium suspension and kept for incubation in a Petri dish for $30 \mathrm{~min}$. Then explants were dried using sterilized filter paper to absorb the additional bacterial suspension and cocultured in the dark on MS supplemented with $4.0 \mu \mathrm{M}$ BAP. Maintaning three days of co-cultivation the explants were washed three-four times with sterilized distilled water followed by incubation for $10 \mathrm{~min}$ with sterilized distilled water containing $300 \mathrm{mg} /$ ticarcillin and finally washed with sterile distilled water. The washed explants were soaked on a sterile Whatman filter paper and cultured on the regeneration medium with $100 \mathrm{mg} / \mathrm{t}$ ticarcillin to control the overgrowth of bacteria. After 2 weeks, the regenerated shoots were subcultured in the selection medium containing $100 \mathrm{mg} /$ kanamycin and $100 \mathrm{mg} /$ ticarcillin. The selection pressure of was gradually increased from $100 \mathrm{mg} \Lambda$ up to $200 \mathrm{mg} /$ kanamycin. The expression of the GUS gene was monitored by GUS histochemical assay (Jeffereson et al. 1987) by submerging the putative transformed shoots in the X-gluc (5-bromo, 4-chloro, 3-indolyl $\alpha$-D glucuronide) solution and incubated at $37^{\circ} \mathrm{C}$ for $24-48 \mathrm{hrs}$. After $48 \mathrm{hrs}$ the putative transformed shoots were bleached with $70 \%$ ethanol 3 - 4 days and observed under stereomicroscope for GUS expression.

For the confirmation of stable integration of GUS and nptll genes the genomic DNA was isolated from the transformed shoots and confirmed by PCR analysis. CTAB method (Doyle and Doyle 1990) was used for DNA isolation. For the detection of the nptII coding sequence, DNA was subjected to PCR using the following primers: forward-5'-TAG CTT CTT GGG TAT CTT TAA ATA-3' and reverse-3'-CCA GTT ACC TTC GGA AAA AGA GTT-5'. For the GUS gene the primers were: forward 5'-CCT GTA GAA ACC CCA ACC CG-3' and reverse 5'-TGG CTG TGA CGC ACA GTT CA-3'. All primers were used at a concentration of $10 \mathrm{pmol} / \mu \mathrm{l}$. The DNA isolated from Agrobacterium tumefaciens strain LBA4404 (plasmid pBI121 containing the GUS and nptII genes) was used as the positive control. Master mixture was prepared by mixing all of the PCR components e.g. 10x buffer, dNTPs, $\mathrm{MgCl}_{2}$, Primer-F and R, polymerase enzyme etc. The final volume of each PCR reaction was $25 \mu \mathrm{l}$. For PCR amplification of the GUS and nptII gene, DNA was denatured at $95^{\circ} \mathrm{C}$ for $5 \mathrm{~min}$ and then amplified in 30 cycles using $94^{\circ} \mathrm{C}$ for $1 \mathrm{~min}, 56^{\circ} \mathrm{C}$ for $1 \mathrm{~min}$ (annealing) and $72^{\circ} \mathrm{C}$ for $1 \mathrm{~min}$ (extension) followed by $5 \mathrm{~min}$ at $72^{\circ} \mathrm{C}$ (final extension). The amplified DNA was separated on $0.8 \%$ agarose gel and stained with ethidium bromide $(0.04 \mu \mathrm{l} / \mathrm{ml})$ and photographed using a gel documentation system (microDOC CSL-MDOCUV3121D).

\section{Results and Discussion}

An efficient and effective in vitro regeneration protocol is a prerequisite for the development of transgenic plants through genetic transformation of any crop plant (Gardner 1993). Therefore, several attempts were made for the establishment of a suitable 
in vitro regeneration method for local varieties of mungbean before conducting genetic transformation experiments. Generally, grain legumes have been considered recalcitrant due to their passiveness to in vitro techniques (Mroginski and Kartha 1984). Consequently, the development of desired transgenic plants is reported to be hampered mainly due to the absence of efficient gene delivery system in grain legumes (Nisbet and Webb 1990). In the present investigation in vitro regeneration studies were carried out using two different types of explants (CADE and $\mathrm{CN}$ ) derived from the two local varieties of mungbean (Binamoog-5 and BARI Mung-6) following the earlier reports using identical varieties of mungbean (Sarker and Siddiqua 2004, Hoque et al. 2007, Islam and Islam 2010).

In the present study, different concentrations of BAP, Kn and NAA were used either singly or in combinations in MS to evaluate their effects on shoot regeneration and ultimately to find out the optimum combinations and concentrations of growth regulators for the initiation and development of multiple shoots from the explants of CADE and CN. Responses of two different explants from two varieties (Binamoog-5 and BARI Mung-6) towards in vitro regeneration of shoots on MS supplemented with different concentrations and combinations of BAP, NAA and Kn are presented in Tables 1 and 2 . The different concentrations and combinations of auxin and cytokinin under the

Table 1. Effect of different concentrations of BAP in MS on regeneration of shoots from CADE explants from two varieties of mungbean.

\begin{tabular}{lccccc}
\hline Variety & $\begin{array}{c}\text { BAP } \\
\text { concentration } \\
(\mu \mathrm{M})\end{array}$ & $\begin{array}{c}\text { \% of } \\
\text { responsive } \\
\text { explants }\end{array}$ & $\begin{array}{c}\text { Days to } \\
\text { shoot } \\
\text { initiation }\end{array}$ & $\begin{array}{c}\text { Mean no. of } \\
\text { shoots/explant after } \\
\text { 60 days of culture }\end{array}$ & $\begin{array}{c}\text { Average } \\
\text { length of } \\
\text { shoots }(\mathrm{cm})\end{array}$ \\
\hline Binamoog-5 & 2.0 & 60 & $12-15$ & $6.3 \pm 0.77$ & $3.2 \pm 0.97$ \\
BARI Mung-6 & $\mathbf{4 . 0}$ & $\mathbf{8 2}$ & $\mathbf{1 2 - 1 3}$ & $\mathbf{8 . 3} \pm \mathbf{0 . 6 1}$ & $\mathbf{4 . 3} \pm \mathbf{0 . 6 5}$ \\
& $\mathbf{6 . 0}$ & 66 & $12-14$ & $6.5 \pm 0.74$ & $3.5 \pm 0.51$ \\
& $\mathbf{2 . 0}$ & 62 & $12-15$ & $5.3 \pm 0.51$ & $3.1 \pm 0.78$ \\
& $\mathbf{4 . 0}$ & $\mathbf{7 8}$ & $\mathbf{1 3 - 1 4}$ & $\mathbf{7 . 3} \pm \mathbf{0 . 5 0}$ & $\mathbf{4 . 1} \pm \mathbf{0 . 4 9}$ \\
\hline
\end{tabular}

in vitro condition have been reported to greatly influence the morphogenesis of plants (Skoog and Miller 1957). BAP is considered as the most widely used and effective cytokinin for in vitro regeneration of shoots in grain legumes, including Vigna species (Gulati and Jaiwal 1994, Sahoo et al. 2002, Saini and Jaiwal 2002). Therefore, in the present investigation MS supplemented with different concentrations of BAP $(2-6 \mu \mathrm{M})$ were used to examine the effects of BAP on multiple shoot induction and their subsequent development from the two explants. 
It was observed that among different concentrations of BAP, MS medium supplemented with $4.0 \mu \mathrm{M}$ of BAP was found to be the best hormonal supplement in producing multiple shoot for both varieties of mungbean. It was observed that almost $80 \%$ of the CADE explants responded to in vitro regeneration in both Binamoog-5 and BARI Mung- 6 when cultured on MS medium containing $4.0 \mu \mathrm{M}$ of BAP (Table 1).

MS medium supplemented with $4.0 \mu \mathrm{M}$ BAP with different combinations and concentrations of $\mathrm{Kn}$ and NAA were used for multiple shoot induction directly from CN explants of Binamoog-5 and BARI Mung-6 varieties. In these hormonal supplements, more than $90 \%$ of $\mathrm{CN}$ explants were found to respond in the both varieties (Table 2).

Table 2. Effect of different concentrations of BAP, Kn and NAA in MS on regeneration of multiple shoots from CN explants of two mungbean varieties, Binamoog-5 and BARI Mung-6.

\begin{tabular}{|c|c|c|c|c|c|c|c|}
\hline \multirow[b]{2}{*}{ Explants } & \multicolumn{3}{|c|}{ Hormonal conc. $(\mu \mathrm{M})$} & \multirow{2}{*}{$\begin{array}{c}\% \text { of } \\
\text { responsive } \\
\text { explants }\end{array}$} & \multirow{2}{*}{$\begin{array}{l}\text { Days to } \\
\text { shoot } \\
\text { initiation }\end{array}$} & \multirow{2}{*}{$\begin{array}{l}\text { Mean no. of } \\
\text { shoots /explant } \\
\text { after } 60 \text { days }\end{array}$} & \multirow{2}{*}{$\begin{array}{c}\text { Average } \\
\text { length of } \\
\text { shoots }(\mathrm{cm})\end{array}$} \\
\hline & BAP & $\mathrm{Kn}$ & NAA & & & & \\
\hline \multicolumn{8}{|c|}{ Binamoog -5} \\
\hline \multirow{10}{*}{$\mathrm{CN}$} & 2.0 & - & - & 62 & $12-13$ & $2.3 \pm 1.16$ & 3.0 \\
\hline & 4.0 & - & - & 88 & $13-15$ & $8.4 \pm 0.74$ & 4.5 \\
\hline & 6.0 & - & - & 64 & $12-13$ & $4.2 \pm 0.87$ & 3.6 \\
\hline & 4.0 & 0.5 & - & 90 & $10-15$ & $7.5 \pm 0.49$ & 4.3 \\
\hline & 4.0 & 1.0 & - & 82 & $10-12$ & $4.0 \pm 0.74$ & 5.0 \\
\hline & 4.0 & 1.5 & - & 72 & $13-14$ & $2.2 \pm 0.50$ & 3.6 \\
\hline & 4.0 & - & 0.2 & 86 & $10-12$ & $8.5 \pm 0.54$ & 4.1 \\
\hline & 4.0 & - & 0.5 & 95 & $8-10$ & $12.0 \pm 0.36$ & 5.2 \\
\hline & 4.0 & - & 1.0 & 74 & $12-13$ & $7.2 \pm 0.77$ & 3.6 \\
\hline & \multicolumn{7}{|c|}{ BARI Mung-6 } \\
\hline \multirow{9}{*}{$\mathrm{CN}$} & 2.0 & - & - & 60 & 10-12 & $2.5 \pm 0.62$ & 3.2 \\
\hline & 4.0 & - & - & 84 & $11-12$ & $7.5 \pm 0.82$ & 4.2 \\
\hline & 6.0 & - & - & 74 & $15-16$ & $4.2 \pm 0.95$ & 3.2 \\
\hline & 4.0 & 0.5 & - & 88 & $10-15$ & $6.5 \pm 0.68$ & 5.1 \\
\hline & 4.0 & 1.0 & - & 80 & $10-12$ & $4.0 \pm 0.49$ & 4.6 \\
\hline & 4.0 & 1.5 & - & 72 & $13-14$ & $3.2 \pm 0.75$ & 3.2 \\
\hline & 4.0 & - & 0.2 & 84 & $10-12$ & $6.6 \pm 0.67$ & 4.0 \\
\hline & 4.0 & - & 0.5 & 92 & $10-12$ & $10.5 \pm 0.62$ & 5.0 \\
\hline & 4.0 & - & 1.0 & 62 & $12-13$ & $8.4 \pm 0.68$ & 3.2 \\
\hline
\end{tabular}

In this case the regenerated shoots were found to be healthy, deep green and leaves were appeared to be larger. An average of 12.0 and 10.5 shoots per $\mathrm{CN}$ explants was produced on MS supplemented with $4.0 \mu \mathrm{M}$ BAP and $0.5 \mu \mathrm{M}$ NAA in case of Binamoog5 and BARI Mung-6, respectively (Table 2). It was observed that for both the varieties, the maximum number of shoots was developed following culture of the explants for $60-70$ 
days. It was further recorded that the average length of fully developed regenerated shoots was $5.0-5.2 \mathrm{~cm}$ in these two varieties. Fig. 3 is presented to show various stages of plantlet regeneration from $\mathrm{CN}$ explants from Binamoog-5.
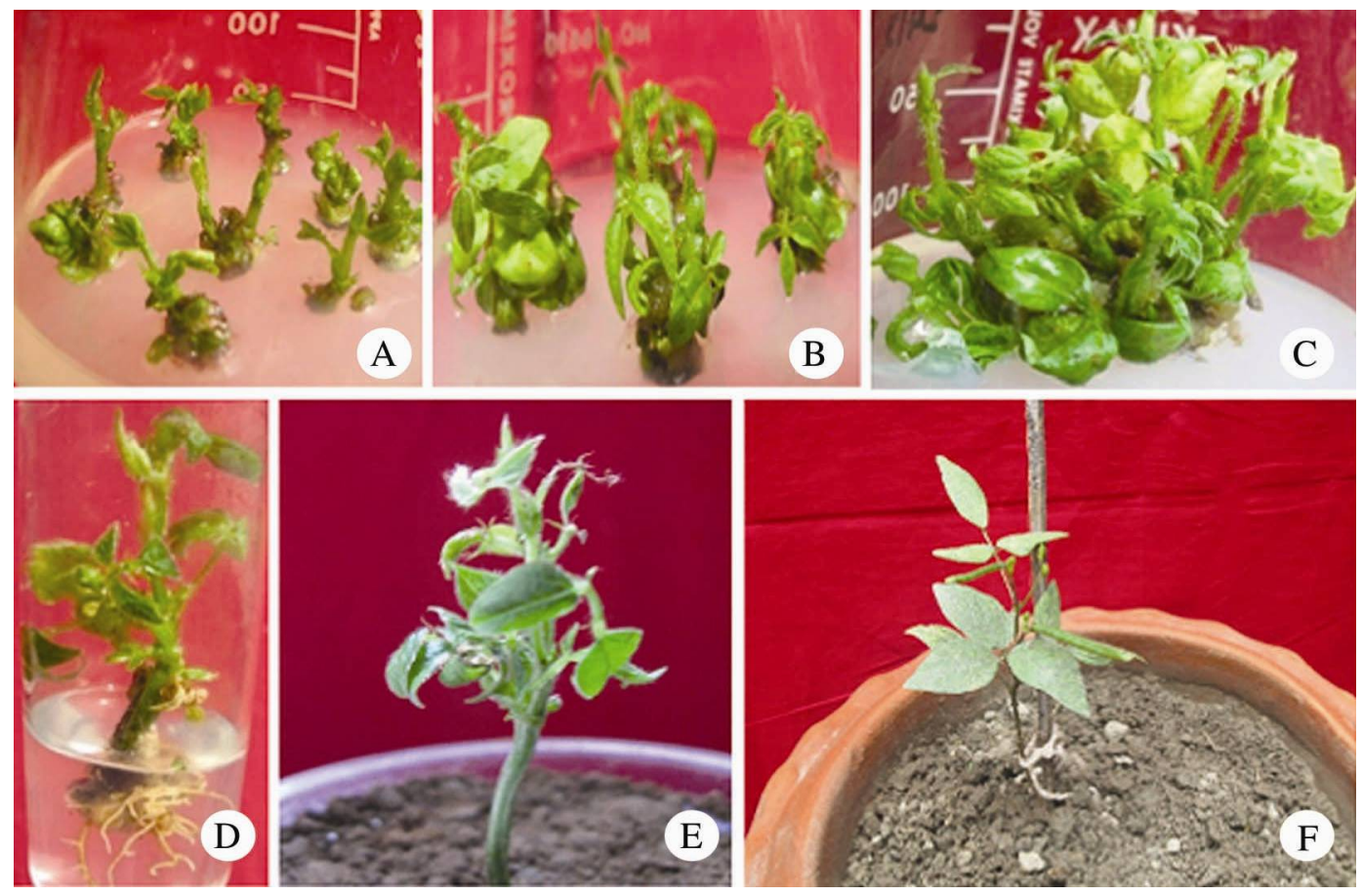

Fig. 3. In vitro regeneration of shoots from $\mathrm{CN}$ explants of Binamoog-5 variety on MS supplemented with $4.0 \mu \mathrm{M}$ BAP and $0.5 \mu \mathrm{M}$ NAA. A. Initiation of shoots. B. Proliferation of shoots. C. Multiple shoots formation on same medium. D. Rooting on half strength MS containing $2.0 \mu \mathrm{M}$ IBA. E. Rooted plantlet transferred to soil in pot. F. Development of pods on fully developed regenerated plant.

The number as well as the growth of in vitro regenerated shoots was maintained by subculturing the explants on MS medium supplemented with only $2.0 \mu \mathrm{M}$ BAP. This reduced concentration of BAP in the subculture medium was found to be very effective in enhancing the subsequent growth of regenerated shoots. During this subculture the shoots were found to be elongated with the formation of new shoots.

In an earlier experiment Hoque et al. (2007) reported that the explants of cotyledon produced multiple shoots on MS supplemented with $0.5 \mathrm{mg} / \mathrm{BAP}$ and $0.1 \mathrm{mg} / \mathrm{kn}$ in case of Binamoog-5. Himabindu et al. (2014) induced multiple shoots from cotyledonary nodal segments when cultured on Gamborg's B5 medium containing $0.5 \mathrm{mg} / \mathrm{BA}$ in an Indian cultivar. Further, in another local cultivar of India, Patra et al. (2018) obtained multiple shoots when $\mathrm{CN}$ explants were cultured on MS containing $1.5 \mathrm{mg} / \mathrm{BAP}$ in 
combination with $1.0 \mathrm{mg} \Lambda \mathrm{Kn}$. In another set of experiments, Yadav et al. (2010) reported that $2.0 \mathrm{mg} / \mathrm{BAP}$ was effective in producing shoots and reduced concentration of BAP was found to be more effective in enhancing multiple shoot formation. Multiple shoot regeneration from CADE explants was found on $1.0 \mathrm{mg} / \mathrm{BAP}$ in MS by Islam and Islam (2010).

Induction of healthy root from the regenerated shoot is an essential part for successful development of complete plantlets. For root induction, regenerated shoots were cultured on both full and half strength of MS supplemented with various concentrations of IAA and IBA. It was observed that root induction occurs when half strength of MS with different concentrations of auxins was used for mungbean varieties. Half strength of MS containing 2.0 $\mu \mathrm{M}$ IBA was found to be effective for root induction and for its subsequent development for both varieties of mungbean tested. Effects of different concentrations of IBA with MS on root formation in Binamoog-5 has been presented in Table 3. Using the same variety Hoque et al. (2007) observed identical responses towards root induction on half strength of MS with $0.5 \mathrm{mg} /$ IBA. However, the responses of the excised shoots towards root induction in auxin supplement medium was found to relatively low due to the recalcitrant nature of the mungbean plants.

Table 3. Effects of different concentrations of IBA with MS on root formation in Binamoog-5.

\begin{tabular}{ccccc}
\hline $\begin{array}{c}\text { Concentrations } \\
\text { of IBA }(\mu \mathrm{M})\end{array}$ & $\begin{array}{c}\text { \% of shoots } \\
\text { forming roots }\end{array}$ & $\begin{array}{c}\text { Days to initiate } \\
\text { roots }\end{array}$ & $\begin{array}{c}\text { Mean number of } \\
\text { roots shoots }\end{array}$ & $\begin{array}{c}\text { Days required to get } \\
\text { well developed roots }\end{array}$ \\
\hline $\mathbf{1 . 0}$ & 12 & $15-16$ & $10 \pm 0.71$ & $32-33$ \\
$\mathbf{1 . 5}$ & 15 & $13-15$ & $12 \pm 1.20$ & $32-34$ \\
$\mathbf{2 . 0}$ & $\mathbf{2 5}$ & $\mathbf{1 3 - 1 5}$ & $\mathbf{1 9} \pm \mathbf{0 . 5 8}$ & $\mathbf{3 0 - 3 2}$ \\
$\mathbf{2 . 5}$ & 18 & $14-16$ & $15 \pm 0.78$ & $32-35$ \\
\hline
\end{tabular}

Agrobacterium-mediated genetic transformation was initiated for the two varieties of mungbean such as, Binamoog-5 and BARI Mung 6 using both $\mathrm{CN}$ and CADE explants to find out the best explants for transformation. It may be mentioned here that Agrobacterium-mediated genetic transformation has been considered as the most common and successful method used in various leguminous crop plants such as soybean (Hinchee et al. 1988; Meurer et al. 1998), chickpea (Fontana et al. 1993, Kar et al. 1996), peanut (McKently et al. 1995, Sarker et al. 2003) and lentil (Sarker et al. 2019). Mungbean is an under exploited crop since limited biotechnological studies has been made so far for its improvement in comparison to other pulse crops. There are a few reports of the production of transgenic mungbean plants using Agrobacterium-mediated genetic transformation (Jaiwal et al. 2001, Mahalakshmi et al. 2006, Sarker and Siddiqua 2004, Hoque el al. 2010, Islam and Islam 2010). 
During the present study the transforming ability of the explants was examined using GUS histochemical assay (Fig. 4) following the method of Jefferson (1987). Among the two explants investigated, CADE from both the varieties showed higher transient GUS expression as confirmed by histochemical assay following the infection of explants with Agrobacterium strain LBA4404 (Table 4). Stereo microscopic view of GUS expression for CADE explant has been shown in Fig. 4 D. In this case the CADE explant was found to be produced conspicuous indigo blue colour. Yadev et al. (2010) reported identical results when cotyledonary node was used in Agrobacterium-mediated transformation, on the other hand Mahalakshmi et al. (2006) found that primary leaf explants (cut at the node) was more effective in genetic transformation with Agrobacterium strain.

Table 4. Responses of explants of Binamoog-5 and BARI Mung-6 variety of mungbean towards genetic transformation with Agrobacterium strain LBA4404 containing the binary plasmid pBI121 analyzed by transient GUS histochemical assay.

\begin{tabular}{lcccc}
\hline Variety & Explant & $\begin{array}{c}\text { No. of explants } \\
\text { assayed for GUS }\end{array}$ & $\begin{array}{c}\text { No. of GUS +ve } \\
\text { explants }\end{array}$ & $\begin{array}{c}\text { \% of GUS +ve } \\
\text { explants }\end{array}$ \\
\hline Binamoog-5 & CN & 200 & 113 & 56.50 \\
\cline { 2 - 5 } & CADE & 250 & 226 & 90.40 \\
\hline BARI Mung-6 & CN & 150 & 79 & 52.60 \\
\cline { 2 - 5 } & CADE & 200 & 162 & 81.00 \\
\hline
\end{tabular}

The method of Agrobacterium-mediated genetic transformation is believed to be influenced by several factors (Mansur et al. 1993). The factors that influence successful transformation including Agrobacterium strain, genotype of the host, explant type, incubation period of the explants, density of the bacterial suspension have been optimized during the present investigation. The introgression of GUS reporter gene was monitored through GUS histochemical assay in the present study.

Transformation efficiency of the explants, in both the varieties was found to be maximum when optical density of bacterial suspension was 0.6 at $600 \mathrm{~nm}$. Moreover, 30 min incubation period followed by $72 \mathrm{hrs}$ of co-cultivation were found to be most effective towards transformation (data are not presented).

In preliminary investigations Jaiwal et al. $(1998,2001)$ and Tazeen and Mirza (2004) reported that $\mathrm{OD}$ of 1.0 and 3 days of co-cultivation period was optimum for transformation of Vigna radiata, while Islam and Islam (2010) found that $45 \mathrm{~min}$ incubation and OD of 1.3 at $600 \mathrm{~nm}$ and $72 \mathrm{hrs}$ co-cultivation was suitable in achieving adequate transformation in mungbean varieties.

Following the procedure of co-cultivation, the CADE explants were transferred to regeneration medium to obtain shoots through organogenesis. The best response towards 
shoot development was achieved for both the varieties when infected CADE explants were cultured on MS supplemented with $4.0 \mu \mathrm{M}$ of BAP (Fig. 4).
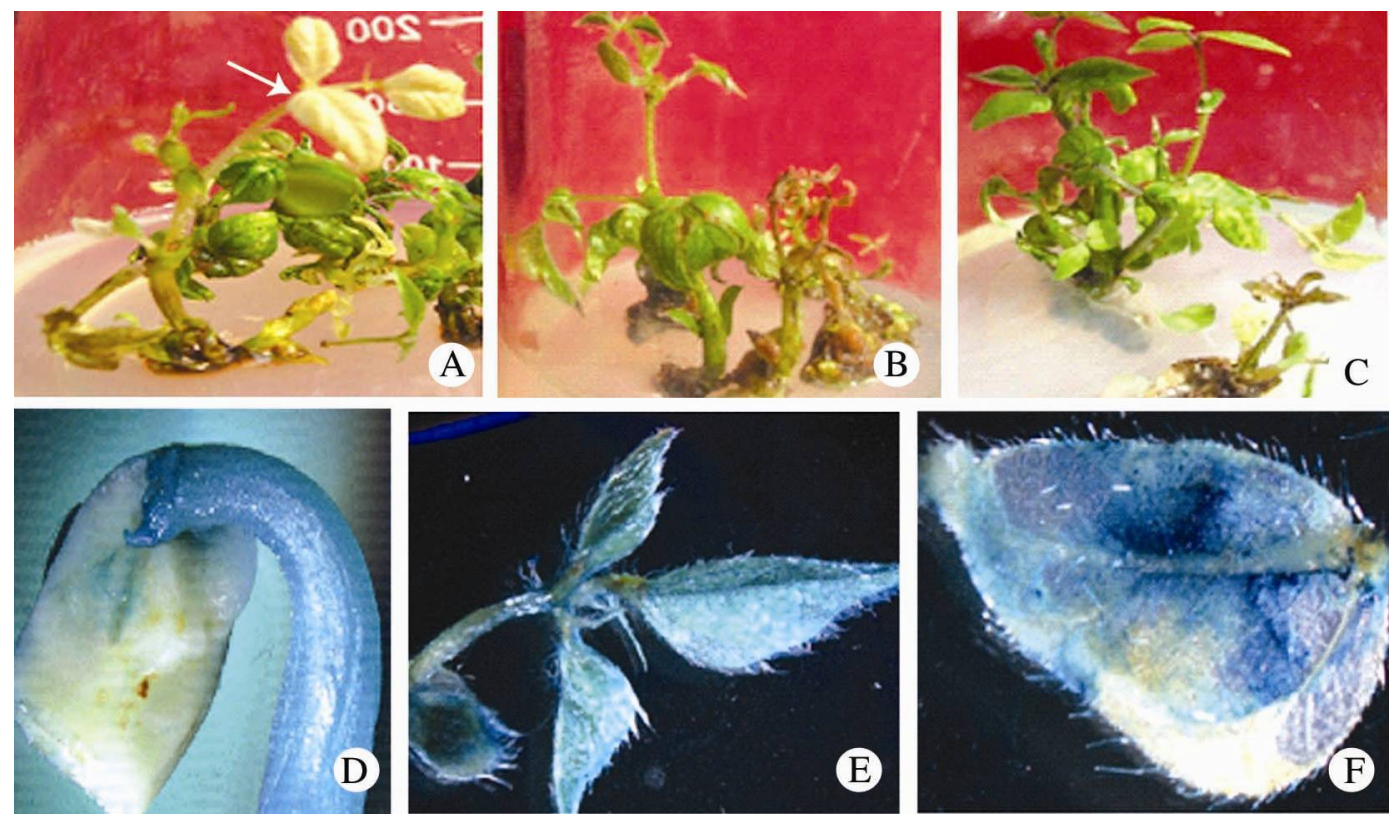

Fig. 4. A. Putatively transformed shoot of Binamoog-5 survived on the selection medium containing 200 $\mathrm{mg} / \mathrm{k}$ kanamycin, where the non-transformed shoots (arrow) became albino in case of CADE explants. A, B \& C. Shoots recovering through selection pressure of kanamycin. D. Histochemical localization of GUS activity in CADE explants. E. Same as D but in case of regenerated shoot obtained through selection. F. Same as E but showing conspicuous blue colour in a leaf.

Since the Agrobacterium strain LBA4404 has nptll gene within their T-DNA and this gene confers kanamycin resistance to the transformed cells, therefore the selection of the transformants was carried out using various concentrations of kanamycin. However, it was observed that presence of kanamycin greatly hampered the growth of the explants and as a result many putative transformants failed to grow. For this reason, immediately after co-cultivation kanamycin was not applied for selection, rather, co-cultivated explants were first allowed to regenerate in regeneration media without any selective agents. After 15 - 20 days the transformed explants with small shoots $(2.0-3.0 \mathrm{~cm})$ were subjected to selection pressure of kanamycin. It was reported that a preculture period and a delayed selection was useful in obtaining regeneration with high transformation frequency in grain legume. This observation is identical to the results obtained in other plant species including flax, alfalfa, peanut and chickpea, where a preculture period and/ or a delayed selection with kanamycin was used in obtaining regeneration from explants with high transformation frequency (Pezzotti et al. 1991, McHughen et al. 1989, Cardi et al. 1992, Sarker et al. 2000, Sarker et al. 2003). 
For the selection of transformants, a higher concentration of kanamycin was applied to screen the transformed shoots effectively. For this purpose, kanamycin concentration was gradually increased from $50-200 \mathrm{mg} / \mathrm{l}$. During this investigation, it was found that all the control shoots failed to survive at $200 \mathrm{mg} / 1$ kanamycin within 15 - 20 days. Gradual elimination of non-transformed shoots was carried out to recover transformed shoots through separating green shoots from albino and brown shoots and allowing their further growth on fresh regeneration medium having higher concentration of kanamycin. Therefore, the shoots survived in the medium containing $200 \mathrm{mg} / \mathrm{l}$ kanamycin were considered as putatively transformed (Table 5). Recovery of the putative transformed shoots following adequate selection pressure has been shown in Fig. 4 (A, B, C). Shoots that survived in the final selection pressure were subjected to rooting on a rooting medium i.e., MS containing 2.0 $\mathrm{MM}$ IBA. It was observed that overall responses towards root formation from shoots those obtained following kanamycin selection.

Table 5. Selection of putative transformed shoots (selectable agent kanamycin).

\begin{tabular}{lcccccccc}
\hline Variety & Explant & $\begin{array}{c}\text { No. of } \\
\text { explants } \\
\text { infected }\end{array}$ & $\begin{array}{c}\text { No. of } \\
\text { shoots } \\
\text { inoculated }\end{array}$ & \multicolumn{2}{c}{$\begin{array}{c}\text { No. of survived shoots in regeneration } \\
\text { media with kanamycin }(\mathrm{mg} /)\end{array}$} & $\begin{array}{c}\text { \% of } \\
\text { survived } \\
\text { shoots }\end{array}$ \\
\hline Binamoog-5 & $\mathrm{CN}$ & 500 & 340 & 210 & 95 & 25 & 6 & 1.7 \\
& CADE & 500 & 420 & 232 & 105 & 42 & 12 & 2.8 \\
BARI Mung-6 & $\mathrm{CN}$ & 500 & 340 & 210 & 95 & 28 & 5 & 1.4 \\
& $\mathrm{CADE}$ & 520 & 450 & 245 & 112 & 45 & 10 & 2.2 \\
\hline
\end{tabular}

Histochemical GUS assay was also performed to detect the expression of GUS gene in the fully developed transformed plantlets growing in soil. Stable expression of GUS was visualized in plant parts (shoots and leaves) of the putative transformed plantlets. Very prominent characteristic indigo blue colour in shoots and leaves (Fig. 4, E and F) indicated the stable integration of GUS gene in the regenerated plantlet. After enough development of roots from the selected shoots, the plantlets were successfully transplanted to soil. But the survival rate of these plantlets was low compared to the controls. The low survival rate of the transformed plantlets in the soil is most likely due to the lack of adequate root development or the proper acclimatization of the plantlets.

The transgenic nature of the transformed plantlets was confirmed through the application of specific molecular techniques like PCR analysis. The DNA isolated from both of transformed and non-transformed shoots was subjected to PCR for the amplification of GUS and nptII gene. Amplified DNA was analyzed through agarose gel electrophoresis (Fig. 5). In case of nptII a single band of $800 \mathrm{bp}$ was observed in six transformed plantlets identical to the amplified DNA of Agrobacterium strain LBA4404- 
pBI121 (positive control). On the other hand, in case of GUS a single band of $750 \mathrm{bp}$ was observed in one transformed plantlet identical to the amplified DNA of the bacterial strain. This result indicated that the GUS and nptII genes were inserted in the genome of only one transformed plantlets. The insertion of single gene was also in reported previous studies (Hassan 2006).

The protocol developed here for in vitro regeneration of local varieties of mungbean using the explants of $\mathrm{CN}$ and $\mathrm{CADE}$ requires very simple growth regulator supplements and appears to be less complicated. This regeneration protocol appeared to be compatible with Agrobacterium-mediated transformation. Moreover, the selection procedure developed during this study has been found to be effective in recovering transformed plantlets. This selection technique can be used in future experiments to develop transgenic mungbean plants more efficiently. Therefore, this transformation protocol
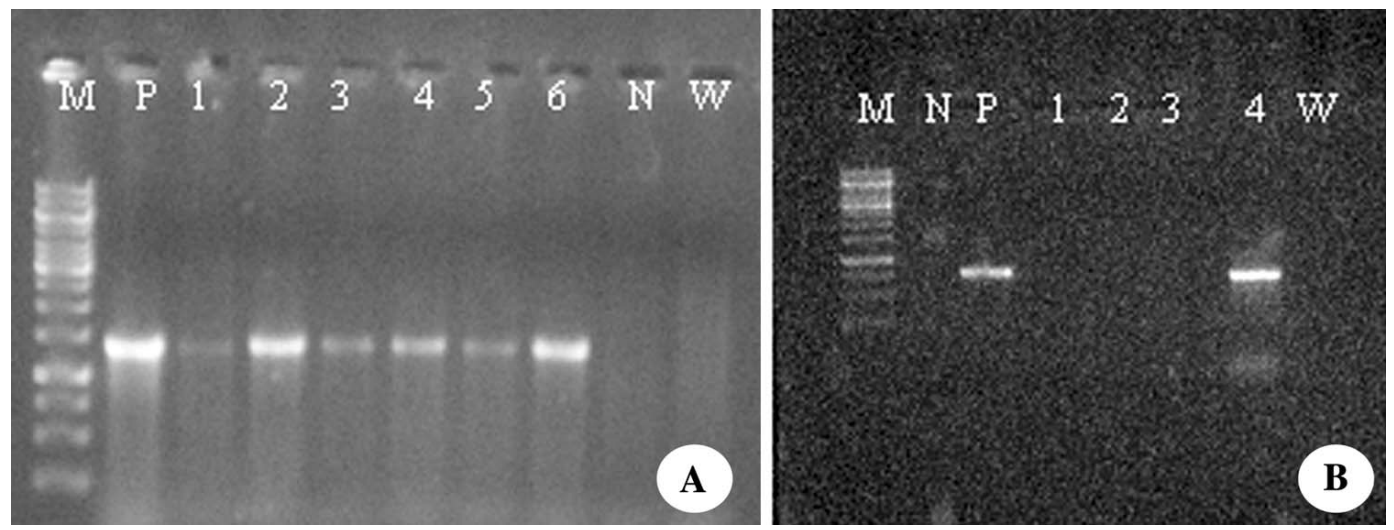

Fig. 5. PCR analysis of transgenic mungbean plants using primers for nptII and GUS gene. A. for nptII gene: Lane $\mathrm{M}=1.0 \mathrm{~kb}$ DNA ladder; Lane $\mathrm{P}=$ DNA from positive control (Bacteria), Lanes $(1-6)=$ DNA from putative transgenic samples, Lane $\mathrm{N}=\mathrm{DNA}$ from negative control (plant) and Lane $\mathrm{W}=$ Water control. B. PCR analysis of mungbean transgenic for GUS gene: Lane $\mathrm{M}=1.0 \mathrm{~kb}$ DNA ladder; Lane $\mathrm{P}=$ DNA from positive control (Bacteria), Lanes 4 = DNA from putative transgenic samples, Lane $\mathrm{N}=$ DNA from negative control (plant) and Lane $\mathrm{W}=$ Water control.

developed using marker genes can be exploited in the future transformation experiments with specific gene/s of interest for the improvement of mungbean varieties grown in Bangladesh. This technique of transformation can be exploited particularly for the development of yellow mosaic virus disease, insect and pest resistant mungbean variety.

\section{Acknowledgements}

This investigation was supported by the BAS-USDA Program in Agricultural and Life Sciences (PALS) through a project entitled "Development of Mungbean Genotypes Conferring Yellow Mosaic Virus (YMV) Resistance". Authors are grateful to the 
authorities of Bangladesh Academy of Sciences for providing the grant to support this project. Authors are thankful to BINA and BARI authorities for providing mungbean seeds for this investigation.

\section{Reference}

AVRDC (2000) Asian Vegetable Research and Development Center.

BBS (2016) Bangladesh Bureau of Statistics, Statistical Yearbook of Bangladesh, Statistics Division, Ministry of Planning, GOB.

Bhadra SK, Hammatt N and Davey MR (1989) Prospects for the use of in vitro technique the improvement of Vigna pulses. SABRAO J. 21(2): 75-91.

Borah BK and Dasgupta I (2012) Begomovirus research in India: A critical appraisal. Bioscience. 37(4): 791-806.

Chavan VM, Patil GD and Bhapker DG (1966) Improvement of cultivated Phaseolus species need for interspecific hybridization. Indian J. Genet. Plant Breed. 26(A): 152-154.

Cardi T, Jannamico V, Ambrosio FD, Filippone E and Lurquin PF (1992) Agrobacterium-mediated genetic transformation of Solanum commersonii Dun. Plant Sci. 87: 179-189.

Chand R, Pal C, Singh V and Chouwadappa P (2015) Draft genome sequence of Cercospora canescens: A leaf spot causing pathogen. Curr. Sci. 109: 2103-2110.

Doyle JJ and Doyle JL (1990) Isolation of plant DNA from fresh tissue. Focus 12: 13-15.

Fontana GS, Santini L, Caretto S, Frugis G and Mariotti (1993) Genetic transformation in the grain legume Cicer arietinum L. Plant Cell Rep. 12: 194-198.

Gardner RC (1993) Gene transformation into tropical and sub tropical crops. Scientia Hort. 55: 65-82.

Gnanaraj M, Udhayakumar N, Gandhi R and Manoharan K (2015) Isolation and gene expression analysis of phospholipase $\mathrm{C}$ in response to abiotic stresses from Vigna radiata (L.) Wilczek. Indian J. Exp. Biol. 53: 335-341.

Gulati A and Jaiwal PK (1994) Plant regeneration from cotyledonary node explants of mung bean [Vigna radiata (L.) Wilczek ]. Plant Cell Rep. 13: 500-505.

Hassan F (2006) Heterologous expression of a recombinant chitinase from Streptomyces olivaceoviridis ATCC 11238 in transgenic pea (Pisum sativum L.). Ph.D. thesis, Hannover University, Germany.

Herrera-Estrella L, Depicker A, Van Montagu M and Schell J (1983) Expression ofchimeric genes transferred into plant cells using a Ti-plasmid-derived vector. Nature 303: 209-213.

Himabindu Y, Madhava CR and Chandrasekhar T (2014) In vitro regeneration of green gram [vigna radiata (L.) wilczek] cultivar vamban-2 using cotyledonary node. CIBTech J. Biotechnol. 3(4): 11-15.

Hinchee MAW, Conner-Ward DV, Newell CA, McDonnell RE, Sato SJ, Gasser CS, Fischhoff DA, Re DB, Fraley RT and Horsch RB (1988) Production of transgenic soybean plants using Agrobacterium-mediated DNA transfer. Nat Biotechnol. 6: 915-922.

Hoque MI, Zahan MM and Sarker RH (2007) In vitro plant regeneration in mungbean (Vigna radiata (L.) Wilczek). Plant Tissue Cult. \& Biotech. 17(2): 209-216. 
Islam MN and Islam KT (2010) Agrobacterium-mediated genetic transformation of mungbean Vigna radiata (L.) Wilczek]. Plant Tissue Cult. \& Biotech. 20(2): 233-236.

Jacobsen HJ (1992) Biotechnology applied to grain legumes - current state and prospects. In: Proceedings of Ist European Conference on Grain Legumes, Angers, France. pp. 99-103.

Jaiwal PK, Sautter C and Potrykus I (1998) Agrobacterium rhizogenes mediated gene transfer in mungbean [Vigna radiata (L.) Wilczek]. Curr. Sci. 75: 41-45.

Jaiwal PK, Kumari R, Ignacimuthu S, Potrykus I and Sautter C (2001) Agrobacterium tumefaciensmediated genetic transformation of mungbean [Vigna radiata (L). Wilczek]. a recalcitrant grain legume. Plant Sci 61: 239-47.

Jefferson R A, Kavanagh T A and Beran M W (1987) Gus fusion: $\beta$-glucuronidase as a sensitive and versatile gene fusion marker in higher plants. EMBO J. 3: 3901-3907.

Kar S, Johnson TM, Nayak P and Sen SK (1996) Efficient transgenic plant regeneration through Agrobacterium-mediated transformation of chickpea (Cicer arietinum L). Plant Cell Rep. 16: 32-37.

Mahalakshmi SL, Leela T and Manoj Kumar S (2006) Enhanced genetic efficiency of mungbean by use of primary leaf explants. Curr. Sci. 91: 93-98.

Mansur EA, Lacortee C, DeFreitus VG, DeOliviera DE, Timmerman B and Cordeiro AR (1993) Regulation of transformation efficiency of peanut (Arachis hypogea L.) explants by Agrobacterium tumefaciens. Plant Sci. 89: 93-99.

McHughen A, Jordan M and Feist G (1989) A preculture period prior to Agrobacterium inoculation increases production of transgenic plants. J. Plant. Physiol. 135: 245-248.

Mckently AH, Mooreg A, Doostdar H and Niedz RP (1995) Agrobacterium-mediated transformation of peanut (Arachis hypogaea L.) embryo axes and the development of transgenic plants. Plant Cell Reports. 14: 699-703.

Meurer CA, Dinkins RD and Collins GB (1998) Factors affecting soybean cotyledonary node transformation. Plant Cell Rep. 18: 180-186.

Mirza B and Tanzeen S (2004) Factors affecting Agrobacterium tumefaciens mediated genetic transformation of Vigna radiata (L.) Wilczek. Pakistan J. Bot. 36 (4): 887-96.

Mroginski LA and Kartha KK (1984) Tissue culture of legumes for crop improvement. In: Plant Breeding Revision 2, Janick J (Ed.), The AVI Publishing Company Incorporation, Westport, Cannecticut. pp. 215-264.

Nariani TK (1960) Yellow mosaic of mung (Phaseolus aureus L.). Indian Phytopathol. 13: 24-29.

Nair R, Schafleitner R, Easdown W, Ebert A, Hanson P, Hughes JA and Keatinge JDH (2014) Legume Improvement Program at AVRDC The World Vegetable Center: Impact and Future Prospects. Ratar. Povrt. 51: 1 55-61

Nisbet GS and Webb KJ (1990) Legumes and Oilseed Crops. In: Bajaj, YPS (Ed.), Biotechnology in Agriculture and Forestry, Springer-Verlag, Berlin. 10(1): 38-48.

Parihar AK, Basandrai AK, Sirari A, Dinakaran D, Singh D, Kannan K, Kushawaha KPS, Adinarayan M,Akram O, Latha TKS, Paranidharan V and Gupta S (2017) Assessment of mungbean genotypes for durable resistance to Yellow Mosaic Disease: Genotype by Environment interactions. Plant Breed. 136: 94-100. 
Patra AP, Samal1 K C, Rout1 G R, Sahu S and Jagadev P Narayan (2018) In vitro regeneration of recalcitrant green gram [Vigna radiata $(\mathrm{L}$.) Wilczek] from immature cotyledons for genetic improvement. Int. J. Curr. Microbiol. App. Sci. 7(1): 3072-3080.

Pezzotti M, Pupilli F, Damiani F and Arcioni S (1991) Transormation of Mediacgo sativa L. using a Ti-plasmid derived vector. Plant Breed. 106: 39-46.

Poehlman JM (1991) The mungbean Oxford and IBH Publishing Co. Pvt. Ltd., New Delhi, India.

Saini R and Jaiwal PK (2002) Age, position in mother seedling, orientation, and polarity of the epicotyl segments of blackgram (Vigna mungo L. Hepper) determines its morphogenic response. Plant Sci. 163: 101-109.

Sahoo L, Sugla T and Jaiwal PK (2002) In vitro regeneration and genetic transformation of Vigna species. In: PK Jaiwal, RP Singh, eds, Biotechnology for the Improvement of Legumes, Kluwer, Dordrecht pp. 1-48.

Sarker RH, Islam MN, Islam A and Seraj ZI (2000) Agrobacterium-mediated genetic transformation of peanut (Arachis hypogaea L.). Plant Tissue Cult. 10(2): 137-142.

Sarker RH, Mustafa B M, Biswas A, Mahbub S, Nahar M and Hashem R (2003) In vitro regeneration of lentil (Lens culinaris Medik.). Plant Tissue Culture 13(2):155-163.

Sarker RH and Siddiqua K Murshida (2004) In book: In vitro application in crop improvement,

Chapter: In vitro plant regeneration and preliminary studies on Agrobacterium-mediated genetic transformation of mungbean, Publisher: Science Publishers, Inc. USA, UK, Editors: A. Mujib, Myeong-je Cho, S. Predieri, S. Banerjee PP: 155-167.

Sarker RH, Das SK, Shethi KJ and Hoque MI (2019) Genetic Transformation, In: Lentils Potential Resources for Enhancing Genetic Gains, Mohar Singh (Ed.) Elsevier Academic Press, pp. 141-202.

Schroeder HE, Schotz AH, Wardley-Richardson T, Spencer D and Higgins TJV (1993) Transformation and regeneration of two cultivars of pea (Pisum sativum L.). Plant Physiol. 101: 751-757.

Shanmugasundaram S and Kim DH (1996) Mungbean. In: Genetics, cytogenetics, and breeding of crop plants, vol. 1. Pulses and oilseeds, ed. P.N. Bahl and P. M. Salimath. New Delhi, India: Oxford and IBH publishing Co.

Shah MJ, Ahmad S, Hussain M, Yousaf, MM and Ahmad B (2007) Efficiency of different insecticides against sucking insect pest complex and effect on the growth and yield of mungbean (Vigna radiata L.). Pakistan J. Entomol. 2: 29.

Skoog F and Miller CO (1957) Chemical regulation of growth and organ formation inplant tissue cultures in vitro. Symp. Soc. Exp. Biol. 11: 118-131.

Verma RPS and singh DP (1986) Problems and prospects of interspecific hybridization involving greengram and blackgram. Indian J. Agric. Sci. 56: 535-537.

Yadav SK, Sreen P, Maheswari M, Vanaja M and Vekenteswaralu B (2010) Efficient shoot regeneration from double cotyledonary node explants of green gram (Vigna radiata (L). Wilzcek). Indian J. Biotechnol. 9: 403407. 